\title{
Model of Higher Education Performance Based on Total Quality Human Resource Management (TQHRM) and Knowledge Strategy
}

\author{
Kusnendi $^{1}$, Askolani ${ }^{2}$, Annisa Ciptagustia ${ }^{3}$ \\ Program Studi Pendidikan Ekonomi, FPEB, Universitas Pendidikan Indonesia, Bandung, Indonesia ${ }^{1}$ \\ Program Studi Manajemen, FPEB, Universitas Pendidikan Indonesia, Bandung, Indonesia ${ }^{2}$ \\ Program Studi Manajemen, FPEB, Universitas Pendidikan Indonesia, Bandung, Indonesia ${ }^{3}$
}

\begin{abstract}
Universities are organizations with inputs and outputs in the form of human resources so that in achieving quality graduates required quality input. By improving the quality of lecturers and educational staff is a quick way to improve the quality of graduates. In addition, in the process of transformation, organizational support is needed through an organization-focused culture of knowledge. In this case, colleges are trying to optimize what they have to determine the right strategy. Based on our previous research results the commitment of human resources is the factor that most influence the performance of universities. One way that is used is to associate the concept of quality with human resource management as a system of human resource improvement, which is with total quality human resource management (TQHRM). This study aim to develop a performance model of higher education organizations based on TQHRM and Knowledge Strategy. This research use survey method. This research is done at the Universitas Pendidikan Indonesia (UPI) with the subject of research is all academic units consisting of graduates study program which amounts to 71 departments. Because this research develops a model which is more formative then more suitable to use Partial Least Square (SEM-PLS). The result finding in Universitas Pendidikan Indonesia, TQHRM and Knowledge Strategy does not affect the performance of the organization. In using the indicators of organizational performance using balance scorecard in higher education is required assumptions include (1) the clarity and alignment of key performance indicators and performance appraisal university courses, (2) high organizational commitment of his teachers.
\end{abstract}

Keywords: Higher education; total quality human resource management (TQHRM); knowledge strategy

Article history. Received Agustus, 2018. Revised Oktober, 2018. Accepted December, 2018

Corresponding author. E-mail address: ${ }^{1}$ kusnendi@ upi.edu, ${ }^{2}$ askolani@ upi.edu, $\underline{3}$ annisacipta@ upi.edu

How to cite article. Ciptagustia, A. (2018). Model of Higher Education Performance Based on Total Quality Human Resource Management (TQHRM) and Knowledge Strategy. The International Journal of Business Review (The Jobs Review), 1(2), 123-130. https://doi.org/https://doi.org/10.17509/tjr.v1i2.14205

\section{INTRODUCTION}

Currently there are factors driving changes in the concept of competition university, including: (1) the effects of globalization, which makes the whole university in the world is a competitor, (2) the output of education is directed to human resources globally competitive, (3) development of the internet make it to monopolize the production of knowledge but towards environmental cooperative with a focus on the client. There has been a reform in educational policy, as the educational market has become liberalized and forced into examining reviews their operations from a decidedly business-like perspective. (Stewart, AC \& Carpenter-Hubin, J. (2001)

The debate is Higher education is a public sector organization that provide educational services with an orientation to improve the quality of graduates. To Determining quality depend on the perspective it takes. Differences of view will determine the qualified graduates will result in Determining factors. The implication is the difference of indicators in assessing the performance of higher education. Required research on the performance of higher education in the perspective of the company as an evaluation of the college vision and mission applications to Achieve qualified graduates. With the purpose of finding a critical point will be an obstacle to improving the 
performance of the organization from all perspectives both financial and non-financial. It is called Balance scorecard. (Indrajit and Djokoprananto (2006) Reviews These dimensions are crucial to provide an effective framework for performance management (Archer, 2007; Carr, 2005; Jones, 2 004; Lee, 2006; Syfert et al., 1998). The conceptualization of the BSC was done with an underlying goal of linking business activities with the strategy, all directed towards achieving the which the ultimate end result is organizational performance (Dkhili and Noubbigh, 2013).

Organizations in analogy as living things that change, conflict, interaction with the environment and disruption whose members are independent people consciously coordinated by the same needs and accommodated by the management. The result is affected by the changes, both internal and external conditions. A healthy organization that is able to survive, it comes from the ability of its members or the people in it who are able to use and develop the potential to cope with these changes. So that the health of the organization can be observed through the behavior of its members or human relations. But it would be hit by the perception of the individual, it is necessary to use a clear measure of the health of the organization one of them with the organization's performance. (Mas'ud, 2004).

Organizational performance is the outcome or result of the performance of the individual in it with the support of management. In order to achieve organizational performance and to minimize the impact of disruption required quality standards are clear and equal to or adopt the concept of total quality. The concept of total quality is a must for the whole organization is no exception university. Total quality is very important because as the same quality standards in order to output or results according to plan and will minimize errors. This concept is known as total quality management (TQM). Based on the results of Chepkech (2014), TQM practices include top management commitment, employee involvement, and focus on the consumer. The results indicate that implementation TQM positive and significant effect on the performance of the organization of educational institutions in Kenya. Where the greatest influence given by the sub-variables of employee involvement. In addition TQM positive and significant impact on the performance of the organization of educational institutions in Iraq. TQM indicator used is the commitment of leadership, strategic planning, improved sustainability, customer focus, focus on the process, employee involvement, training and learning, reward and management by fact. While the performance of universities use the academic sector and non-academics. (Zwain, 2012)

With TQM, organizations get quality products that have met the organization scenario. Because of the university's main business is the necessary human knowledge and total quality concept will focus on human performance and manage knowledge. One of them is the concept of TQM approach and HRM or referred to as total quality human resource management (TQHRM).

Higher education is an organization that uses knowledge in all aspects of the system work that is of input, process and output as well. So how to accumulate knowledge of the individual in order to accumulate into organizational knowledge. Hence the need for a knowledge management strategy for the university as a high chance of the transformation process of individual knowledge and ability of the individual to be a system of individual and organizational development is formal. (Ramanigopal, 2012) Similarly, the research Kasten (2007) that required the support of the management in the form of stimulus working environment, procedure or strategic policy to create an innovative climate either by applying knowledge strategy. Knowledge strategy not only manage individual knowledge but how to become a knowledge organization as a source of innovation. This is what makes the organization more adaptive to change and the ability of innovation that will affect the performance of the organization.

The assumption that the organization as a system of social interaction that consists of transformational and transactional processes. Transactional processes is a change in the daily 
behavior of its members that affect the performance of individuals in the form of policies and procedures, management practices, climate unit, motivation while the transformational process is behavioral change significantly which can alter the performance of the organization include leadership, vision and strategy, and organizational culture. TQHRM is transactional and transformational processes at once when applying the development and improvement of employee engagement strategy while knowledge is a transformational process. TQHRM then is how to prepare qualified human resources while Knowledge Strategy create an organizational culture that supports innovation of human resources. Whole will produce outcomes or outputs in the achievement of organizational performance.

The purpose of this study is to describe and to analyze the influence of TQHRM and knowledge strategy toward organizational performance in higher education.

TQHRM is The full potential of employee empowerment is realized in the empowered organization, when employees: align their goals with appropriate higher organization purpose; have the authority and opportunity to maximize their contribution; are capable of taking appropriate action; are committed to the organization's purpose; and have the means to achieve it. (Juran, 1999). From these explanations that TQHRM is one approach of human resource management that involve the concept of quality management that emphasizes human resource quality improvement process through the empowerment process with employee satisfaction output. (Jain and Gupta, 2012).

TQHRM has two main activities: (1) Employee management system whose activities are proactive and focus on development to improve employee motivation, which consisted of three programs including: the annual, six-month process, and the process of development. (2) Empowered management long-term system, starting from the evaluation of the activities in the organization and eliminate ineffective. The steps are (a) Alignment is that employees must be aligned with the mission and goals of the organization where employees need to know organizations characteristic, both from the needs and desires of customers and stakeholders, know-agreed and prepare the business to contribute in achieving organizational goals. (b) Authority is every employee a chance and have the authority to maximize the contribution that transparency and fairness in formulating personal authority-responsibility-and a consistent ability, in addition to the organizations providing support in the necessary facilities. (c) Capability is the skills and abilities of the employees is very important for a foundation in acting. Apart from the motivation of individual employees of the organization call for support through a series of capacity building training activities of employees in other. (d) Commitment from within the individual to succeed so that the initiative to develop the personal capabilities and given awards and recognition system of the organization. In this study using indicators of Jain and Gupta (2012), namely Empowered management system consisting of (1) Alignment, (2) Authority, (3) Capability, (4) Commitment.

Based on a report from the US General Accounting Office (GAO) (1991) that the implementation TQHRM will optimize organizational performance by improving the quality, employee participation, cooperation, labor relations, customer satisfaction, employee satisfaction, productivity, communication, profitability and market share. To achieve optimal performance of the organization required a high commitment of management and employees before working on the performance of other resources. ${ }^{1}$

Referring to the theory and the result of previous studies, the first hypothesis proposed TQHRM influence toward organizational performance.

\section{H1: TQHRM effect on organizational performance}

\footnotetext{
${ }^{1}$ www.mechastrolines.blogspot.co.id

125 | The International Journal of Business Review (The Jobs Review) Vol.1 | No.2 | 2018
} 
Knowledge Strategies is a general resource of the human condition and closely linked to the learning process to making a decision. Eric Cheng (2012). Indicators of knowledge strategy in this study consisted of three indicators, namely: (1) Knowledge Retrieval refers to the gathering of information and knowledge for planning, decision making and problem solving. It involves the process of capturing the existing knowledge through formal representations and acquire the necessary knowledge and information. (2) Knowledge utilization is activities implementing or use the knowledge to make a strategic decision, the act of taking information and modify behavior. (3) Knowledge Sharing is the sharing of knowledge, experience and knowledge distribution process.

Higher education is an organization that uses knowledge in all aspects of the system work that is of input, process and output as well. So how to accumulate knowledge of the individual in order to accumulate into organizational knowledge. Hence the need for a knowledge management strategy for the university as a high chance of the transformation process of individual knowledge and ability of the individual to be a system of individual and organizational development is formal. (Ramanigopal, 2012) Knowledge Strategy is a stimulus working environment, procedure or strategic policy to create an innovative climate and how to become a knowledge organization as a source of innovation. This is what makes the organization more adaptive to change and the ability of innovation that will affect the performance of the organization. (Kasten, 2007; Zack, 1999)

According to the basic theory is explained and the result of previous studies, it can be Formulated the second hypothesis as follows:

\section{H2: Knowledge Strategy affect the improvement of organizational performance}

University organization is public sector organization which is not focus on profit but to focus on providing services or products to serve the community and make a profit (surplus) - quasi non-profit. (Indrajit Djokoprananto, 2006) Since the main business is education so that the performance organsiasi seen improved quality of their education. Therefore the approach Balanced Scorecard can be an alternative assessment that accommodates the university organizational performance indicators of the financial and non-financial. The indicators are: (1) The customer perspective consisting of accreditation, (2) Perspective finance, namely in terms of the absorption of the budget of each program of study, (3) internal perspective consists of digits Efficiency Education (AEE), (4) Perspective growth seen from the number of professors and associate professor.

\section{RESEARCH METHOD}

Unit of analysis is the study program D3 and S1 at the University of Indonesia, which amounts to 71 study programs. The sampling technique is saturated with the sample data source that is a lecturer. This type of research is explanative research with quantitative approach so that the method used is survey method. Analysis tool used is descriptive statistics to determine the position of each of the variables and to predict the relationship between the study variables using Structural Equation Model - Partial Least Square (PLS-SEM). Because the study was to develop a model which is more formative it is more appropriate to use the Partial Least Square (PLS-SEM).

\section{RESULTS AND DISCUSSION}

Based on the results of the processing of descriptive statistics of the study variables obtained summary as follows:

Table 1 Descriptive Statictics 


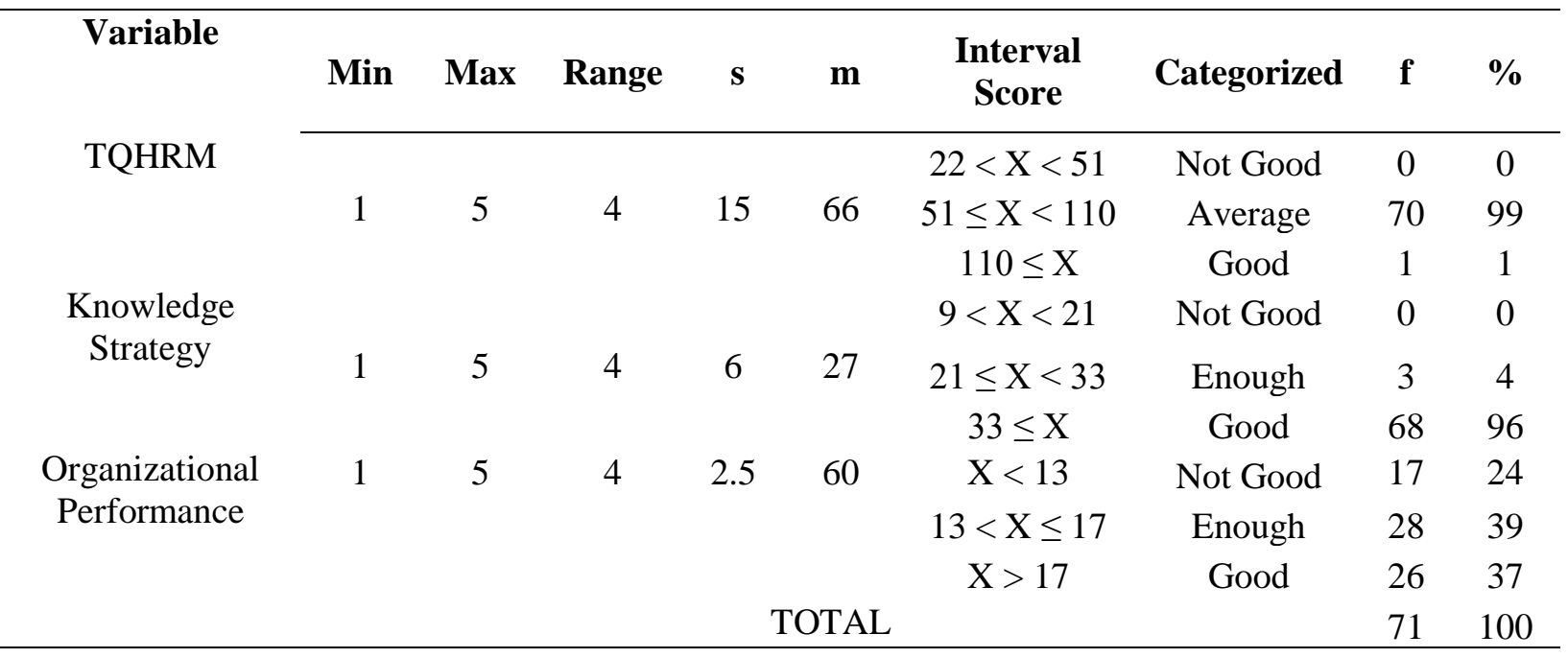

Table 1 obtained information that the 95\% confidence level, variable TQHRM in Indonesian Education University (UPI) in enough categories, application of category strategy is good knowledge and variable performance of the organization in the category enough. Judging from the distribution, showing $99 \%$ or 70 courses in its TQHRM UPI level in the category enough. A total of $1 \%$ or 1 course of his TQHRM good level. Application of knowledge strategy in 28 courses or $39 \%$ category of pretty, 26 courses or $37 \%$ implementation has been good and 17 courses or $24 \%$ is not optimal in its application. Meanwhile, looking at the total score of each indicator variable research is described Table 2.

Table 2. Score Total Indicators

\begin{tabular}{|c|c|c|c|}
\hline Variabel & Indicators & Score & $(\%)$ \\
\hline \multirow[t]{4}{*}{ TQHRM } & Alingment & 2503 & $38 \%$ \\
\hline & Authority & 1469 & $22 \%$ \\
\hline & Capability & 1493 & $22 \%$ \\
\hline & Commitment & 1223 & $18 \%$ \\
\hline Variabel & Indicators & Score & $(\%)$ \\
\hline \multirow[t]{3}{*}{ Knowledge Strategy } & Knowledge Utilization & 2503 & $38 \%$ \\
\hline & Knowledge Sharing & 1469 & $22 \%$ \\
\hline & Knowledge Retrieval & 1493 & $22 \%$ \\
\hline \multirow[t]{4}{*}{ Organizational Performance } & Customer Perspective & 313 & $29 \%$ \\
\hline & Internal Perspective & 258 & $24 \%$ \\
\hline & Financial Perspective & 294 & $28 \%$ \\
\hline & Growth Perspective & 199 & $19 \%$ \\
\hline
\end{tabular}

Table 2 get indicator lowest variable TQHRM is the commitment and the highest score is alignment. It is indicated that the lack of commitment of human resources, in accordance with the results of previous studies that the level of commitment of human resources is still low at UPI. 
(Askolani, Annisa, Tresna; 2016) From the observations, there is a trigger factor that employment status as a civil servant is situational factors, which do not require optimum performance for performance appraisal results are not proportional to income and career paths are organizational factors consequently affects the working attitude civil servant whose work is not based on a target. Yet it is the harmony which is already aware of the need for stakeholders (students and the world of work) and try to achieve the goals set into initial capital for universities to achieve optimal performance with a record of making commitments organizational of lecturer improvement strategy.

In the variable knowledge lowest indicators that the activity strategy of knowledge sharing and knowledge retrieval. While activity was considered optimal utilization of knowledge. But overall there is no dominant indicator. According to the results of observation, not yet formalized scientific discussion activities among lecturer and so hard to make the process of knowledge creation.

Of variable performance of the organization, the customer perspective into the highest indicator through the accreditation assessment indicate that public confidence in the quality of UPI has been adequately recognized. Financial perspective as seen from the achievement of budget absorption was already in fairly good condition. Judging from the internal perspective of education efficiency figures imply accountability criteria and the amount of funds to be obtained. Because AEE as an indication of the success of the educational process. However, the growth perspective seen from the number of professors and Lector head is still low. This phenomenon is a challenge throughout Indonesia that the number of professors still less when compared to other Asian countries.

From the results of outer model (Fig.), TQHRM as latent variable 1, Knowledge Strategy as Latent Variable 2 and Organizational Performance as a latent variable 3. The results show that the model is not significant. Then in UPI, TQHRM and Knowledge Strategy does not affect the performance of the organization.

Basically to use the indicator of organizational performance with a balanced scorecard should be able to define key performance indicators that cooperation between universities and study programs. But in fact, the study programs have not obvious performance indicators and targets that are in line with the university strategic goals. (Sudirman, 2012) (Al Hosaini, Sofian, 2015) In addition, the university need to encounter obstacles that generally come from the employee. Such barriers include resistance to change, lack of commitment, or the fear of accountability pressures. From this research, it was found that the level of commitment of its employees is still low so that it can be used as a justification that TQHRM UPI has not been able to improve organizational performance. 


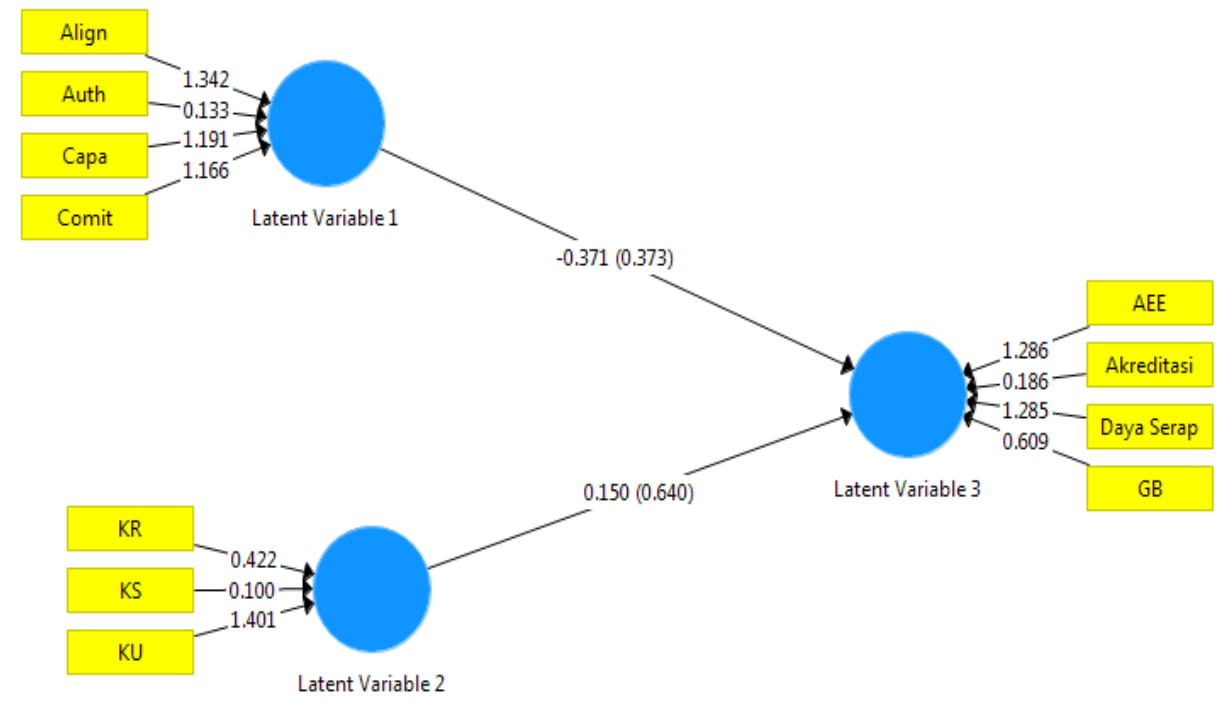

Fig.1. Calcuate PLS Algorithm (Outer Model)

\section{CONCLUSION}

In this study, we found in Universitas Pendidikan Indonesia, TQHRM and Knowledge Strategy does not affect the performance of the organization. And TQHRM variable in the UPI in enough categories, application of category strategy is good knowledge and variable performance of the organization in the category enough.

Organizational performance at UPI focused on the customer perspective rather than on an internal perspective or growth that is visible from the variable TQHRM for indicators of commitment HR trend lower, but already the harmony which is already aware of the need for stakeholders (students and the world of work) and try to achieve the goals set. Not yet a culture of knowledge, especially in the process of creating and sharing knowledge. In addition to the implications for the activity in which the strategy has not yet formed knowledge creation and sharing of knowledge culture in the level of formal organizations exist.

In using the indicators of organizational performance using balance scorecard in higher education is required assumptions include (1) the clarity and alignment of key performance indicators and performance appraisal university courses, (2) high organizational commitment of his teachers.

\section{REFERENCES}

Al-Hosaini, Fahmi Fadhl., Saudah Sofian. (2015). A Review of Balanced Scorecard Framework in Higher Education Institution (HEIs). International Review of Management and Marketing Vol. 5, No. 1, 2015, pp.26-35 ISSN: 2146-4405 www.econjournals.com

Archer, J. (2007). Districts tracking goals with balanced scorecards database. Academic Search Premier, 26(24), 10. 
Askolani, Annisa Ciptagustia, Tresna Ramdhani. 2016. Corerelation between TQHRM and Employee Perfromance in Higher Education. Proceeding The 4th Gadjah Mada International Conference on Economics and Business (GAMAICEB) p.481-486. ISSN 2548-7965

Carr, N. (2005). Process meets progress: Borrowing from business in Charlotte-Mecklenburg. American School Board Journal, 24(2), 14-17.

C.RAMANIGOPAL. 2012. International Journal of Advanced Research in Management (IJARM), ISSN 0976 - 6324(Print), ISSN 0976 - 6332 (Online), Volume 3, Issue 1, January- June (2012), p.20-29

Cheng, Eric. 2012. Knowledge Strategies for Enhancing school learning capacity. International Journal of Educational Management, Vol 26 Iss 6 pp.577-592.

Chepkech, W.K. 2014. Effect of TQM Practices on Organziational Performance in Kenya: A Case Study of Teritiary Institutions in UANSIN GINSHU County. Thesis. Kisil University.

Dkhili, H., Noubbigh, H. (2013). Management Control System and the Case of CSR in the Tunisian Industrial Companies: What Findings by the Method of Structural Equation? International Review of Management and Marketing, 3(2), 86-92.

Hansen, M., Nohria, N. and Tierney, T. 1999. Whats your Strategy for managing knowledge?. Harvard Business Review, Vo. 77 No.2, pp.106-116.

Indrajit, R. Eko \& Djokopranoto, R. 2006. Manajemen Perguruan Tinggi Modern. YogyakartaIndonesia: Penerbit Andi.

Jain, Angkur and Gupta, S.L., . 2012. Conceptual Design For Total Quality Human Resource Management System in Software Industry. http://dx.doi.org/10.2139/ssrn.2085061

Jones, K. (2004). A balanced school accountability model: An alternative to high-stakes testing. Phi Delta Kappan, 85(8), 584-590.

Juran, Joseph M. Human Resource And Quality. Exerpted from: Juran's Quality Handbook, 5e. McGraw-Hill,1999.

Kasten, J. 2007. Knowledge Strategy and Its Influence on Knowledge Organziation. Preceedings of The North American Symposium on Knowledge Organziation. Vol.1. http://ldlist.sir.arizona.edu/1907

Lee, N. (2006). Measuring the performance of public sector organisations: a case study on public schools in Malaysia. Measuring Business Excellence, 10(4), 50-64

Stewart, Alice C. and Hubin, Carpenter Julie, (2001). Beyond Report and Ranking, Planning in Higher Education, Winter 2000-2001

Syfert, P., Elliott, N., Schumacher, L. (1998). Charlotte adapts the'balanced scorecard.'. American City \& Country, 113(11), 32.

Zack, M.H. 1999. Developing a Knowedge Strategy. California Management Review, Vol. 41 No.3, pp.125-145.

Zwain, Ammar Abdulammeer. 2012. The Impact of Total Quality Management on Knowelde Management and Organizational Performance in Higher Education Institutions in Iraq. Dissertation. Universiti Utara Malaysia UUUM). Not Published. 